\title{
Influences on brand selection decisions of staple goods: A study on toothpaste users of Khulna city
}

\author{
SANDIP SARKER ${ }^{1,}$, , SALAHUDDIN YOUSUF ${ }^{1}$, MUHTARIM ZUBAIR MONZOOR $^{2}$ \\ ${ }^{1}$ School of Management \& Business Administration, Khulna University, Khulna, Bangladesh \\ ${ }^{2}$ School of Business, University of Alberta, Edmonton, Canada
}

\section{Email address:}

sandip.smiling@gmail.com(S. SARKER), sazib_yousuf@yahoo.com(S. YOUSUF), muhtarimzubair@hotmail.com(M. Z. MONZOOR)

\section{To cite this article:}

SANDIP SARKER, SALAHUDDIN YOUSUF, MUHTARIM ZUBAIR MONZOOR. Influences on Brand Selection Decisions of Staple Goods: A Study on Toothpaste Users of Khulna City. Journal of World Economic Research. Vol. 2, No. 3, 2013, pp. 58-66.

doi: $10.11648 /$ j.jwer.20130203.14

\begin{abstract}
In present society and living way, the Brands not only represent the symbol of the company or product but to a larger extent define the general life of a person. What the person uses can reflect his taste of life, his status in the society, his economic background and many other things. This makes a deep connection between the company and its brand, with the consumer. In today's time customers are very deeply connected to the brands. When they purchase any product like a car, mobile, items of daily need, brand name influence the consumer's choice. Some customers purchase the specific branded things just due to the brand name. Customers believe that brand name is a symbol of quality. Toothpaste is one of the consumer goods that we purchase on a regular basis. This paper has explored the factors that affect the brand selection of toothpaste in the Khulna region. A pilot survey has been conducted to find out the factors regarding the brand selection decision of toothpaste. Then a structured questionnaire has been developed measuring 20 variables. The relative importance of the variables was evaluated by the survey outcomes. Results show that several factors are influential for the toothpaste brand selection e.g. quality, advantages of using product, duration of freshness, Smell, perceived performance, brand awareness, product Attribute etc. The study also reveals the problems and identified probable solutions to overcome these problems.
\end{abstract}

Keywords: Brand, Toothpaste, Variables, Consumer's Choice

\section{Background of the Study}

In our daily life, toothpaste is an integrated part. In fact it is the product with which we start a day. Toothpaste is something that most of us just idly toss into our shopping trolley when we are doing the rounds at the super market, probably not giving it a second thought. But toothpaste has a fascinating history and is subject to debates about which of the huge variety of styles is preferable. Different people prefer different types of toothpaste for their use. The importance of product brand can be seen primarily in its impact on consumers' choice and their loyalty towards the brand through identifying and differentiating quality. In other words, customers will more likely to become loyal to a brand when the particular brand is perceived to provide the level of quality that can meet customers' expectations. There are different types of toothpaste brands available in the market ranging from local to global. In today's competitive business environments, consumers are exposed to a large number of brand choice alternatives. Managers and marketers are battling to keep their brand loyal customer loyal and trying to avoid competitors from grabbing of these customers. There are various factors that consumers consider to select a particular brand of their needed product category. (Wel, Alam \& Nor, 2011). Factors from different sources may affect the choice of a toothpaste brand. Some of the factors may be product specific and some may be external. Some factors may be the emotional outcome of the consumers whereas some of them will be rational. This study intended to examine the factors that could possibly affect the brand selection decision of toothpaste of consumers of Khulna city.

\subsection{A Brief Introduction of Khulna City}

Khulna is the headquarter of Khulna District and the principal city of Khulna Division. It is located in the southern area of Bangladesh and situated on the banks of the Rupsha and Bhairab River. The River port of Khulna is 
one of the oldest River port in Bangladesh. Khulna is the 3rd largest city in Bangladesh. Often referred to as; Industrial City. It is one of the important industrial and commercial area of the country. It has a Sea port named Mongla on its outskirts, $38 \mathrm{~km}$ from Khulna City Which is the 2nd seaport in Bangladesh. Khulna is also the gateway of Sundarban (home of Royal Bengal Tiger). The population of the city (under the jurisdiction of the City Corporation), was 1,000,000 in 2007 estimation. The wider Statistical Metropolitan Area had at the same time an estimated population of $1,435,422$. Like the other big cities of Bangladesh, notably Dhaka and Chittagong, Khulna is undergoing a major transformation, due to its immensely growing population and its status as Bangladesh's third largest city. Because of its strategic location of only $45 \mathrm{~km}$ from the port of Mongla, Khulna is considered as a port city like Chittagong. Khulna is known as the city of shrimp, because $75 \%$ of shrimp exported from Bangladesh are cultivated in the Khulna zone. It is also known for its lobster, prawn, catfish, and crab. Khulna has some heavy and medium industries like Khulna Hardboard Mills, Bangladesh Oxygen Company, Khulna Oxygen Company, Platinum Jubilee Jute Mills, Star Jute Mills, Dada Match Factory (now Dhaka Match Factory) and Khulna Ship Yard Ltd. Many offices of multinational organization are in Khulna city. There are some retail stores like Meena Bazaar and Safe and safe. All classes of people e.g. middle upper and lower can be found in Khulna thus reflects a diversity. Overall the city plays a significant role in the development of Bangladesh.

\subsection{Objectives of the study}

The main objective of this study is to find out the factors that affect the brand selection decision of toothpaste.

To achieve the main objective, several sub objectives are required to achieve:

- Analyze different factors that affect the brand selection decision of toothpaste.

- Measuring the importance of each factor.

- Measuring problems and identifying probable solutions to build positive brand image of a toothpaste brand.

\subsection{Materials and Methods}

\subsubsection{Sources of Information}

Primary Sources: This study focuses on primary data. A primary survey has been conducted to discover the factors which are instrumental to the brand selection decision of toothpaste brand. Therefore twenty (20) important factors have been found and customers are surveyed based on those factors.

Secondary Sources: As secondary source, a lot of journals, books and reports related to brand selection decisions were used.

\subsubsection{Research Questions}

Research questions have been determined after reviewing the existing literature and also evaluating the contexts of local businesses and market set-up. In the process of setting the research questions the prospective future contribution of this research work also has been considered. That was a major concern because the study should be able to contribute something in the existing scientific literatures and also for the development of the country and society. The following research questions have been set afterwards:

- $\quad$ Research Question 1: What factors affect the brand selection decision of toothpaste among the consumers in Khulna city?

- Research Question 2: What measures can be taken to build positive brand image of a toothpaste brand?

\subsubsection{Research Design}

In order to solve the above mentioned research questions and this study has been adopted the following research design comprising data collection and analysis. This study has utilized survey research methodology. A highly structured questionnaire was developed based on discussions with selected university faculty and marketing professionals. The pre-test was conducted for wording, layout, content validity, and determining main data collection methods.

\subsubsection{The Population}

The population of this study is all customers who regularly purchase different toothpaste brands from retail outlets in Khulna city.

\subsubsection{Sampling Design}

A total of 100 customers from the population sectors have been selected with following the Convenience sampling method, a non-probability sampling technique. Sample size has been selected after reviewing a lot of literature and study conducted on similar field. The accuracy of representation also been assured from the evidences of those earlier researches. A total of 100 customers have taken part in interview with structured questionnaire.

\subsubsection{Instrument Development}

\subsubsection{Questionnaire}

Research conduction with the help of questionnaire is the most popular method irrespective of the sectors. It is used in almost every field and business sector is no exception. The main questionnaire has been developed after analyzing the factors received from pilot survey. The questionnaire has been prepared in the context of the brand selection decision. Questionnaire was divided into two parts. First part is all about the general information about the respondents. And the second part is about the factors that affect brand selection decision of toothpaste. Twenty (20) attributes e.g. price, quality, doctor's instruction, herbal 
ingredients, perceived performance, peer group influence, country of origin, availability of information, product attribute etc were selected from the pilot survey. Respondents were asked to rank the factors that they believe affecting their toothpaste brand selection decision. The ranking was ranging from strongly disagree to strongly agree (numerically ranging from $1=$ strongly disagree, $2=$ disagree, $3=$ neutral, $4=$ agree and $5=$ strongly agree).

\subsubsection{Data Collection}

Data was collected directly from the customer with a face to face interview. One month starting from March 01, 2013 to march 30, 2013 was taken for survey conduction and data collection. Apart from that a lot of secondary data will also be collected from different published sources.

\subsubsection{Data Analysis}

The data analysis has been done by utilizing both quantitative and qualitative analysis techniques. This study has conducted the data analysis with the application of SPSS software version 16.0. Data has been analyzed with the help of the literatures of the previous researches of the same field. In order to make the analysis fruitful and goal directed special attention has been given towards fulfilling all the research questions successfully by the process of data analysis. The following four research questions have been analyzed by utilizing the following respective data analysis techniques:

- $\quad$ Research Question 1: What factors affect the brand selection decision of toothpaste among the consumers in Khulna city?

In order to fulfill the first research question: first the outcome of the survey was tabulated. The mean, standard deviation and coefficient of variation scores of the 20 major factors were analyzed from the descriptive statistics. After that measurement of the importance of factors has been done.

- Research Question 2: What measures can be taken to build positive brand image of a toothpaste brand?

In order to fulfill the requirements of the research question 2, descriptive and qualitative analysis has been done for suggesting the ways to build positive brand image of a brand. In order to do so the problem detection and extremity as well as the factor outputs were also considered and thus assisted a lot for the problem eradication suggestion process.

\subsubsection{Measurement of Variables}

The survey questionnaire has measured 20 constraints factors. The factors affecting brand selection decision on toothpaste brand among the consumers in Khulna metropolitan area have been evaluated by those 20 variables in the form of: price, quality, doctor's instructions, herbal ingredients, information about the product, country of origin, brand awareness, product's attributes, TV advertisement, design, credibility of the company, peer group influence, perceived performance, duration of freshness, innovation, parent's influence, advantages of product, taste, product availability and smell. Here, the marketer's concern in Khulna region is the dependent variable and those 20 factors are the independent variables.

\section{Literature Review}

A brand is a name, term, sign, symbol, design or a combination of them, intended to identify the goods or services of one seller or a group of sellers and to differentiate them from those of competitors (Kotler \& Keller, 2009). A brand offers differentiation to customers on the sources of products, and act as a protective medium to distinguish products from competitors that appear to be identical (Low \& Lamb, 2000). Though brand is regards as intangible item, but brand also subject to changes from external forces such as market demand, consumer preferences, technological advancement and other factors. Branding strategy that focus on attributes offering competitive advantage will outperform the competitors (Rajagopal, 2008).

Brand association is defined as "all brand-related thoughts, feeling, perceptions, image, experiences, beliefs, attitudes, and so on that are linked to brand" (Kotler \& Keller, 2009). A set of well-defined brand associations is crucial for the development of rich and clear brand identity. In order to construct a good brand association, the best way is to establish an in depth understanding on their brand and benchmarking their brand association with their competitors through extensive customer research (Ghodeswar, 2008). It is suggested that the marketer needs to firstly identify which attributes in brand association are perceived to be of important value to the consumer for their product category or range. This is because such understanding is needed to formulate the relative competitiveness that the product or services needs to achieve differentiation from competitor are offering (Puth, Mostert, \& Ewing, 1999).

Consumer behavior is the decision processes and acts of people involved in buying and using products. It involves purchasing \& other consumption related activities of people engaging in the exchange process. Behavior of consumer is motivated or purposive. The behavior is directed towards the goal of obtaining products or other resources. It is the activities of people engaged in actual \& potential use of market items-whether products, services, retail environments or ideas (Berkman, 1992).

Fast Moving Consumer Goods (FMCG) goods are popularly named as consumer packaged goods. Items in this category include all consumables (other than groceries/pulses) that people buy at regular intervals. The most common in this list are toilet soaps, detergents, shampoos, toothpaste, shaving products, shoe polish, packaged foodstuff, and household accessories and extends to certain electronic goods. These items are meant for daily use of frequent consumption and have a high return. The sector is divided into two distinct segments - the premium segment catering mostly to the urban upper middle class 
and the popular segment with prices as low as $40 \%$ of the premium segment. (Mahalingam1, S., Kumar, P. Nandha, 2012)

The choice is restricted toward the limited brands in different categories of low involvement products. There is no disagreement on that everyone is facing with a choice. The person walking on a sidewalk, when confronted with a puddle, changes his direction slightly and continues. In this case few people may say that a choice was involved. Attitude of the consumer plays an important role in making decision making in a given situation. A consumer's attitude and purchase intention towards a brand is not only a product of their cognitive evaluations of that individual brand but are also determined by their perception of other competing brands within the consideration set. (Ronnie, Anne, and Karinna, 2006).

Product features (Fragrance / Skin care / Germ fight features / Color) is one of the most important factors that affect brand loyalty. The relationship between the availability of the toilet soap and the extent of brand loyalty was also found to be significant (Mahmud, Khaled \& Gope, Khonika, 2012).

By understanding customers and the roles that brands can play in purchasing, Business can better appreciate the sustainable drivers of brand value and brand equity in their businesses as well as isolating their competitive advantages over other retailers and manufacturers. Brands are an essential part of consumer choices when purchasing products, but to understand why this is the case, firms need to isolate and understand the factors that underlie a brand's importance and what factors lead their own brands to possess a competitive advantage in the marketplace. By understanding the role of brands as market based assets and the relationships that can develop between consumers and particular store and category brands, managers can not only enhance revenue generation, but also be I a better position to predict business outcomes, now and in the future. We know that consumers are the king in the service industry and success largely depends on satisfying consumer needs by delivering valued products and services. Therefore this study will help the service marketers to identify their problems and prospects in developing superior brand value and deliver their goods and services accordingly.

\section{Data Analysis \& Interpretation}

\section{Attribute 1: Price:}

Table 1: Descriptive statistics of the variable "price".

\begin{tabular}{llllll}
\hline & $\mathrm{N}$ & $\begin{array}{l}\text { Minim } \\
\text { um }\end{array}$ & $\begin{array}{l}\text { Maxim } \\
\text { um }\end{array}$ & $\begin{array}{l}\text { Mea } \\
\mathrm{n}\end{array}$ & $\begin{array}{l}\text { Std. } \\
\text { Deviation }\end{array}$ \\
\hline $\begin{array}{l}\text { price and } \\
\text { toothpaste brand } \\
\text { selection }\end{array}$ & 100 & 1 & 5 & 3.23 & 1.109 \\
$\begin{array}{l}\text { Valid N (List } \\
\text { wise) }\end{array}$ & 100 & & & & \\
\hline
\end{tabular}

Observation 1: From the analysis of descriptive statistics and distribution of the variable "price" we can see that customers are not that much price sensitive when it comes to brand selection of toothpaste considering the mean score of 3.23 .

\section{Attribute 2: Quality:}

Table 2: Descriptive statistics of the variable "Quality".

\begin{tabular}{llllll}
\hline & $\mathrm{N}$ & $\begin{array}{l}\text { Minim } \\
\text { um }\end{array}$ & $\begin{array}{l}\text { Maxim } \\
\text { um }\end{array}$ & Mean & $\begin{array}{l}\text { Std. } \\
\text { Deviation }\end{array}$ \\
\hline $\begin{array}{l}\text { quality and } \\
\text { toothpaste brand } \\
\text { selection }\end{array}$ & 100 & 2 & 5 & 4.21 & .795 \\
$\begin{array}{l}\text { Valid N (List } \\
\text { wise) }\end{array}$ & 100 & & & & \\
\hline
\end{tabular}

Observation 2: From the analysis of descriptive statistics and distribution of the variable "quality" we have found that customers believe that quality is an important factor when it comes to toothpaste brand selection.

\section{Attribute 3: Television advertisement:}

Table 3: Descriptive statistics of the variable "TV Advertisement".

\begin{tabular}{llllll}
\hline & N & $\begin{array}{l}\text { Minim } \\
\text { um }\end{array}$ & $\begin{array}{l}\text { Maxim } \\
\text { um }\end{array}$ & Mean & $\begin{array}{l}\text { Std. } \\
\text { Deviation }\end{array}$ \\
\hline $\begin{array}{l}\text { TV. advertisement } \\
\& \text { toothpaste } \\
\text { brand selection }\end{array}$ & 100 & 1 & 5 & 3.21 & 1.094 \\
$\begin{array}{l}\text { Valid N (List } \\
\text { wise) }\end{array}$ & 100 & & & & \\
\hline
\end{tabular}

Observation 3: From the analysis of descriptive statistics and distribution of the variable "TV advertisement" we can see that TV advertisement doesn't affect the brand selection decision of toothpaste in considering its mean value 3.21.

\section{Attribute 4: Doctor's Instructions:}

Table 4: Descriptive statistics of the variable "Doctor's Recommendation".

\begin{tabular}{llllll}
\hline & $\mathrm{N}$ & $\begin{array}{l}\text { Minim } \\
\text { um }\end{array}$ & $\begin{array}{l}\text { Maxim } \\
\text { um }\end{array}$ & Mean & $\begin{array}{l}\text { Std. } \\
\text { Deviation }\end{array}$ \\
\hline $\begin{array}{l}\text { doctor's } \\
\text { recommendation } \\
\& \text { toothpaste } \\
\text { brand selection }\end{array}$ & 100 & 1 & 5 & 3.38 & 1.144 \\
$\begin{array}{l}\text { Valid N (List } \\
\text { wise) }\end{array}$ & 100 & & & & \\
\hline
\end{tabular}

Observation 4: From the analysis of descriptive statistics and distribution of the variable "doctor's recommendation" it has found that doctor's recommendation is not an important factor of brand selection of toothpaste. 


\section{Attribute 5: Herbal Ingredients:}

Table 5: Descriptive statistics of the variable "Herbal Ingredients".

\begin{tabular}{|c|c|c|c|c|c|}
\hline & $\mathrm{N}$ & $\begin{array}{l}\text { Minim } \\
\text { um }\end{array}$ & $\begin{array}{l}\text { Maxim } \\
\text { um }\end{array}$ & Mean & $\begin{array}{l}\text { Std. } \\
\text { Deviation }\end{array}$ \\
\hline $\begin{array}{l}\text { Herbal } \\
\text { ingredients and } \\
\text { toothpaste brand } \\
\text { selection }\end{array}$ & 100 & 1 & 5 & 3.54 & 1.029 \\
\hline Valid N (list wise) & 100 & & & & \\
\hline
\end{tabular}

Observation 5: From the analysis of descriptive statistics and distribution of the variable "herbal ingredients" we have found consumers believe there should be presence of herbal ingredients in the toothpaste brand.

Attribute6: Design And Packaging:

Table 6: Descriptive statistics of the variable "Design \& Packaging".

\begin{tabular}{llllll}
\hline & $\mathrm{N}$ & $\begin{array}{l}\text { Minim } \\
\text { um }\end{array}$ & $\begin{array}{l}\text { Maxim } \\
\text { um }\end{array}$ & Mean & $\begin{array}{l}\text { Std. } \\
\text { Deviation }\end{array}$ \\
\hline $\begin{array}{l}\text { design and } \\
\text { toothpaste brand } \\
\text { selection }\end{array}$ & 100 & 1 & 5 & 2.79 & 1.282 \\
$\begin{array}{l}\text { Valid N (List } \\
\text { wise) }\end{array}$ & 100 & & & & \\
\hline
\end{tabular}

Observation 6: From the analysis of descriptive statistics and distribution of the variable "design \& packaging" we have found that design and packaging is not an important factor for toothpaste brand selection.

Attribute 7: Credibility of the Company:

Table 7: Descriptive statistics of the variable "Credibility of the company".

\begin{tabular}{llllll}
\hline & $\mathrm{N}$ & $\begin{array}{l}\text { Minim } \\
\text { um }\end{array}$ & $\begin{array}{l}\text { Maxim } \\
\text { um }\end{array}$ & Mean & $\begin{array}{l}\text { Std. } \\
\text { Deviation }\end{array}$ \\
\hline $\begin{array}{l}\text { credibility of the } \\
\text { company \& } \\
\text { toothpaste brand } \\
\text { selection }\end{array}$ & 100 & 1 & 5 & 3.74 & 1.292 \\
$\begin{array}{l}\text { Valid N (List } \\
\text { wise) }\end{array}$ & 100 & & & & \\
\hline
\end{tabular}

Observation 7: From the analysis of descriptive statistics and distribution of the variable "credibility of the company" we have found that customers believe they should go for toothpaste brand which company is likely to be credible.

\section{Attribute 8: Peer group influence:}

Table 8: Descriptive statistics of the variable "Peer group influence".

\begin{tabular}{llllll}
\hline & N & $\begin{array}{l}\text { Minim } \\
\text { um }\end{array}$ & $\begin{array}{l}\text { Maxim } \\
\text { um }\end{array}$ & Mean & $\begin{array}{l}\text { Std. } \\
\text { Deviation }\end{array}$ \\
\hline $\begin{array}{l}\text { Peer group } \\
\text { influence \& } \\
\text { toothpaste brand } \\
\text { selection }\end{array}$ & 100 & 1 & 5 & 2.81 & 1.169 \\
$\begin{array}{l}\text { Valid N (List } \\
\text { wise) }\end{array}$ & 100 & & & & \\
\hline
\end{tabular}

Observation 8: From the analysis of descriptive statistics and distribution of the variable "peer group influences" we have found the peer group doesn't influence too much in choosing toothpaste brand.

\section{Attribute 9: Product Perceived Performance}

Table 9: Descriptive statistics of the variable "Product perceived performance".

\begin{tabular}{llllll}
\hline & $\mathrm{N}$ & $\begin{array}{l}\text { Minim } \\
\text { um }\end{array}$ & $\begin{array}{l}\text { Maxim } \\
\text { um }\end{array}$ & Mean & $\begin{array}{l}\text { Std. } \\
\text { Deviation }\end{array}$ \\
\hline $\begin{array}{l}\text { product perceived } \\
\text { performance \& } \\
\begin{array}{l}\text { toothpaste brand } \\
\text { selection }\end{array}\end{array}$ & 100 & 1 & 5 & 4.01 & .882 \\
$\begin{array}{l}\text { Valid N (List } \\
\text { wise) }\end{array}$ & 100 & & & & \\
\hline
\end{tabular}

Observation 9: From the analysis of descriptive statistics and distribution of the variable "Product perceived performance" we have got that product's perceived performance should be high to choose a toothpaste brand.

Attribute 10: Duration of Freshness

Table 10: Descriptive statistics of the variable "Duration of freshness".

\begin{tabular}{llllll}
\hline & $\mathrm{N}$ & $\begin{array}{l}\text { Minim } \\
\text { um }\end{array}$ & $\begin{array}{l}\text { Maxim } \\
\text { um }\end{array}$ & Mean & $\begin{array}{l}\text { Std. } \\
\text { Deviation }\end{array}$ \\
\hline $\begin{array}{l}\text { Duration of } \\
\text { freshness \& } \\
\text { toothpaste brand } \\
\text { selection }\end{array}$ & 100 & 1 & 5 & 4.05 & .880 \\
$\begin{array}{l}\text { Valid N (List } \\
\text { wise) }\end{array}$ & 100 & & & & \\
\hline
\end{tabular}

Observation 10: From the analysis of descriptive statistics and distribution of the variable "Duration of freshness" we have found that customers believe duration of freshness is an important consideration for selecting a toothpaste brand. 


\section{Attribute 11: Availability of product information}

Table 11: Descriptive statistics of the variable "Availability of product information".

\begin{tabular}{llllll}
\hline & $\mathrm{N}$ & $\begin{array}{l}\text { Minim } \\
\text { um }\end{array}$ & $\begin{array}{l}\text { Maxim } \\
\text { um }\end{array}$ & Mean & $\begin{array}{l}\text { Std. } \\
\text { Deviation }\end{array}$ \\
\hline $\begin{array}{l}\text { availability of } \\
\text { product } \\
\text { information \& } \\
\text { toothpaste brand } \\
\text { selection }\end{array}$ & 100 & 1 & 5 & 3.73 & .763 \\
$\begin{array}{l}\text { Valid N (List } \\
\text { wise) }\end{array}$ & 100 & & & & \\
\hline
\end{tabular}

Observation 11: From the analysis of descriptive statistics and distribution of the variable "Availability of product information" we have found that customers believe that they should go for toothpaste brand which information is available.

\section{Attribute 12: Uniqueness \& Innovation:}

Table 12: Descriptive statistics of the variable "Uniqueness \& Innovation",

\begin{tabular}{llllll}
\hline & $\mathrm{N}$ & $\begin{array}{l}\text { Minim } \\
\text { um }\end{array}$ & $\begin{array}{l}\text { Maxim } \\
\text { um }\end{array}$ & Mean & $\begin{array}{l}\text { Std. } \\
\text { Deviation }\end{array}$ \\
\hline $\begin{array}{l}\text { Uniqueness \& } \\
\text { toothpaste brand } \\
\text { selection }\end{array}$ & 100 & 1 & 5 & 3.38 & .874 \\
$\begin{array}{l}\text { Valid N (List } \\
\text { wise) }\end{array}$ & 100 & & & & \\
\hline
\end{tabular}

Observation 12: From the analysis of descriptive statistics and distribution of the variable "Uniqueness or innovation" we have found that customers put less emphasis on this factor in choosing toothpaste brand selection.

\section{Attribute 13: Country of Origin:}

Table 13: Descriptive statistics of the variable "Country of Origin".

\begin{tabular}{llllll}
\hline & $\mathrm{N}$ & $\begin{array}{l}\text { Minim } \\
\text { um }\end{array}$ & $\begin{array}{l}\text { Maxim } \\
\text { um }\end{array}$ & Mean & $\begin{array}{l}\text { Std. } \\
\text { Deviation }\end{array}$ \\
\hline $\begin{array}{l}\text { country of origin } \\
\& \text { toothpaste } \\
\text { brand selection }\end{array}$ & 100 & 1 & 5 & 3.23 & 1.033 \\
$\begin{array}{l}\text { Valid N (List } \\
\text { wise) }\end{array}$ & 100 & & & & \\
\hline
\end{tabular}

Observation 13: From the analysis of descriptive statistics and distribution of the variable "Country of Origin" we have found that country of origin doesn't affect that much on toothpaste brand selection.

\section{Attribute 14: Parent's Influence:}

Table 14: Descriptive statistics of the variable "Parent's influence".

\begin{tabular}{llllll}
\hline & $\mathrm{N}$ & $\begin{array}{l}\text { Minim } \\
\text { um }\end{array}$ & $\begin{array}{l}\text { Maxim } \\
\text { um }\end{array}$ & Mean & $\begin{array}{l}\text { Std. } \\
\text { Deviation }\end{array}$ \\
\hline $\begin{array}{l}\text { parent's influence } \\
\text { \& toothpaste } \\
\text { brand selection }\end{array}$ & 100 & 1 & 5 & 3.35 & 1.019 \\
$\begin{array}{l}\text { Valid N (List } \\
\text { wise) }\end{array}$ & 100 & & & & \\
\hline
\end{tabular}

Observation 14: From the analysis of descriptive statistics and distribution the variable "Parent's influence" we have found that parental influence is a less important factor in toothpaste brand selection.

\section{Attribute 15: Advantages of using product:}

Table 15: Descriptive statistics of the variable "Advantages of using product".

\begin{tabular}{lcllll}
\hline & $\mathrm{N}$ & $\begin{array}{l}\text { Minim } \\
\text { um }\end{array}$ & $\begin{array}{l}\text { Maxim } \\
\text { um }\end{array}$ & Mean & $\begin{array}{l}\text { Std. } \\
\text { Deviation }\end{array}$ \\
\hline $\begin{array}{l}\text { Advantages of } \\
\text { using product \& } \\
\text { toothpaste brand } \\
\text { selection }\end{array}$ & 100 & 1 & 5 & 4.06 & .814 \\
$\begin{array}{l}\text { Valid N (List } \\
\text { wise) }\end{array}$ & 100 & & & & \\
\hline
\end{tabular}

Observation 15: From the analysis of descriptive statistics and distribution of the variable "Advantages of using product" we have got that this has been an important factor for the customers in choosing toothpaste brand selection.

\section{Attribute 16: Taste}

Table 16: Descriptive statistics of the variable "Taste".

\begin{tabular}{llllll}
\hline & $\mathrm{N}$ & $\begin{array}{l}\text { Minim } \\
\text { um }\end{array}$ & $\begin{array}{l}\text { Maxim } \\
\text { um }\end{array}$ & Mean & $\begin{array}{l}\text { Std. } \\
\text { Deviation }\end{array}$ \\
\hline $\begin{array}{l}\text { Taste \& } \\
\text { toothpaste brand } \\
\text { selection }\end{array}$ & 100 & 1 & 5 & 3.77 & .952 \\
$\begin{array}{l}\text { Valid N (List } \\
\text { wise) }\end{array}$ & 100 & & & & \\
\hline
\end{tabular}

Observation 16: From the analysis of descriptive statistics and distribution of the variable "Taste" it is evident that customers give much emphasis on taste while selecting toothpaste brand.

\section{Attribute 17: Product Availability}

Table 17: Descriptive statistics of the variable "Product availability".

\begin{tabular}{llllll}
\hline & $\mathrm{N}$ & $\begin{array}{l}\text { Minim } \\
\text { um }\end{array}$ & $\begin{array}{l}\text { Maxim } \\
\text { um }\end{array}$ & Mean & $\begin{array}{l}\text { Std. } \\
\text { Deviation }\end{array}$ \\
\hline $\begin{array}{l}\text { product } \\
\text { availability \& } \\
\text { toothpaste brand } \\
\text { selection }\end{array}$ & 100 & 1 & 5 & 3.40 & 1.005 \\
$\begin{array}{l}\text { Valid N (List } \\
\text { wise) }\end{array}$ & 100 & & & & \\
\hline
\end{tabular}


Observation 17: From the analysis of descriptive statistics and distribution of the variable "Product availability" we have found that customers give medium emphasis on availability of product while selecting toothpaste brand.

Attribute 18: Smell:

Table 18: Descriptive statistics of the variable "Smell".

\begin{tabular}{llllll}
\hline & $\mathrm{N}$ & $\begin{array}{l}\text { Minim } \\
\text { um }\end{array}$ & $\begin{array}{l}\text { Maxim } \\
\text { um }\end{array}$ & Mean & $\begin{array}{l}\text { Std. } \\
\text { Deviation }\end{array}$ \\
\hline $\begin{array}{l}\text { Smell \& } \\
\text { toothpaste brand } \\
\text { selection }\end{array}$ & 100 & 1 & 5 & 4.03 & .881 \\
$\begin{array}{l}\text { Valid N (List } \\
\text { wise) }\end{array}$ & 100 & & & & \\
\hline
\end{tabular}

Observation 18: From the analysis of descriptive statistics and distribution of the variable "Smell" we have got that smell of a toothpaste brand is an important factor for a consumer to select a toothpaste brand.

Attribute 19: Brand Awareness:

Table 19: Descriptive statistics of the variable "Brand awareness".

\begin{tabular}{lcclll}
\hline & $\mathrm{N}$ & $\begin{array}{l}\text { Minim } \\
\text { um }\end{array}$ & $\begin{array}{l}\text { Maxim } \\
\text { um }\end{array}$ & Mean & $\begin{array}{l}\text { Std. } \\
\text { Deviation }\end{array}$ \\
\hline $\begin{array}{l}\text { Brand awareness } \\
\& \text { toothpaste } \\
\text { brand selection }\end{array}$ & 100 & 1 & 5 & 4.00 & .943 \\
$\begin{array}{l}\text { Valid N (List } \\
\text { wise) }\end{array}$ & 100 & & & & \\
\hline
\end{tabular}

Observation 20: From the analysis of descriptive statistics and distribution of the variable "Brand awareness" we have found that customers believe they should be brand aware to select a particular toothpaste brand.

\section{Attribute 20: Product Attribute:}

Table 20: Descriptive statistics of the variable "Product Attribute".

\begin{tabular}{llllll}
\hline & $\mathrm{N}$ & $\begin{array}{l}\text { Minim } \\
\text { um }\end{array}$ & $\begin{array}{l}\text { Maxim } \\
\text { um }\end{array}$ & Mean & $\begin{array}{l}\text { Std. } \\
\text { Deviation }\end{array}$ \\
\hline $\begin{array}{l}\text { Product attributes } \\
\text { \& toothpaste } \\
\text { brand selection }\end{array}$ & 100 & 2 & 5 & 3.98 & .816 \\
$\begin{array}{l}\text { Valid N (List } \\
\text { wise) }\end{array}$ & 100 & & & & \\
\hline
\end{tabular}

Observation 20: From the analysis of descriptive statistics and distribution of the variable "Product Attribute" we have found that product attribute has been an important factor for a consumer to select that toothpaste brand.

\section{Ranking of factors}

\begin{tabular}{ll}
\hline Name of the Factor & Product Mean Score \\
\hline Quality & 4.21 \\
Advantages of using product & 4.06 \\
Duration of freshness & 4.05 \\
Smell & 4.03 \\
\hline
\end{tabular}

\begin{tabular}{ll}
\hline Perceived performance & 4.01 \\
Brand awareness & 4.00 \\
Product Attribute & 3.98 \\
Taste & 3.77 \\
Credibility of the company & 3.74 \\
Availability of product information & 3.73 \\
Herbal Ingredients & 3.54 \\
Product Availability & 3.40 \\
Uniqueness or Innovation & 3.38 \\
Doctor's Instruction & 3.38 \\
Parents influence & 3.35 \\
Country of Origin & 3.23 \\
Price & 3.23 \\
TV Advertisement & 3.21 \\
Peer group influence & 2.81 \\
Design or packaging & 2.79 \\
\hline
\end{tabular}

Major Findings: From the analysis of the ranking we have found some of the factors which seem to be important factors from customer's point of view. This includes; Perceived performance, Brand awareness, Product Attribute, Taste, Credibility of the company, Availability of product information, Herbal Ingredients. At the same time some factors are less important to them to select a toothpaste brand. This includes; Product Availability, Uniqueness or Innovation, Doctor's Instruction, Parents influence, Country of Origin, Price, TV Advertisement. On the other hand some factors don't affect at all to select toothpaste brand. For example; peer group influence, Design or packaging.

\section{Cross Analysis}

\begin{tabular}{|c|c|c|c|c|c|c|}
\hline $\begin{array}{c}\text { Name of the } \\
\text { factors }\end{array}$ & $\begin{array}{c}\text { Strongl } \\
\mathrm{y} \\
\text { disagre } \\
\mathrm{e}\end{array}$ & $\begin{array}{c}\text { Disagre } \\
\mathrm{e}\end{array}$ & $\begin{array}{c}\text { Neutra } \\
1\end{array}$ & $\begin{array}{c}\text { Agre } \\
\text { e }\end{array}$ & $\begin{array}{l}\text { Strongl } \\
\mathrm{y} \text { agree }\end{array}$ & $\begin{array}{c}\text { Tota } \\
1\end{array}$ \\
\hline Price & 12 & 12 & 21 & 51 & 4 & 100 \\
\hline Quality & 0 & 4 & 11 & 45 & 40 & 100 \\
\hline $\begin{array}{c}\text { TV } \\
\text { advertiseme } \\
\text { nt }\end{array}$ & 7 & 23 & 19 & 44 & 7 & 100 \\
\hline $\begin{array}{l}\text { Doctors } \\
\text { instruction }\end{array}$ & 8 & 14 & 25 & 38 & 15 & 100 \\
\hline $\begin{array}{c}\text { Herbal } \\
\text { ingredients }\end{array}$ & 3 & 16 & 20 & 46 & 15 & 100 \\
\hline $\begin{array}{l}\text { Design and } \\
\text { packaging }\end{array}$ & 24 & 15 & 26 & 28 & 7 & 100 \\
\hline $\begin{array}{l}\text { Credibility } \\
\text { of the } \\
\text { company }\end{array}$ & 9 & 10 & 15 & 30 & 36 & 100 \\
\hline $\begin{array}{l}\text { Peer group } \\
\text { influence }\end{array}$ & 16 & 24 & 30 & 23 & 7 & 100 \\
\hline $\begin{array}{c}\text { 'Product } \\
\text { perceived } \\
\text { performance } \\
\text {, }\end{array}$ & 2 & 4 & 14 & 51 & 29 & 100 \\
\hline $\begin{array}{l}\text { 'Duration of } \\
\text { freshness' }\end{array}$ & 1 & 8 & 6 & 55 & 30 & 100 \\
\hline $\begin{array}{l}\text { Availability } \\
\text { of product }\end{array}$ & 1 & 5 & 25 & 58 & 11 & 100 \\
\hline
\end{tabular}




\begin{tabular}{|c|c|c|c|c|c|c|}
\hline information & & & & & & \\
\hline Uniqueness & 1 & 12 & 46 & 30 & 11 & 100 \\
\hline $\begin{array}{c}\text { Country of } \\
\text { origin }\end{array}$ & 1 & 25 & 40 & 18 & 16 & 100 \\
\hline $\begin{array}{l}\text { Parents } \\
\text { influence }\end{array}$ & 2 & 19 & 36 & 28 & 15 & 100 \\
\hline $\begin{array}{l}\text { Advantages } \\
\text { of using } \\
\text { product }\end{array}$ & 1 & 1 & 21 & 45 & 32 & 100 \\
\hline taste & 1 & 5 & 38 & 28 & 28 & 100 \\
\hline $\begin{array}{c}\text { Product } \\
\text { availability }\end{array}$ & 3 & 20 & 20 & 48 & 9 & 100 \\
\hline Smell & 1 & 5 & 16 & 46 & 32 & 100 \\
\hline $\begin{array}{c}\text { Brand } \\
\text { awareness }\end{array}$ & 2 & 5 & 17 & 43 & 33 & 100 \\
\hline $\begin{array}{l}\text { Product } \\
\text { attribute }\end{array}$ & 0 & 9 & 7 & 61 & 23 & 100 \\
\hline
\end{tabular}

\section{Conclusion \& Discussion}

The study was conducted in the Khulna region to find out the factors that affect the brand selection decision of toothpaste. The results of this study illustrated that some factors e.g. quality, advantages of using product, duration of freshness, Smell, perceived performance, brand awareness, product attribute etc affect consumer's brand selection decision of toothpaste. The findings would be an eye opener to various marketers to identify the factors that affect customer's brand selection decision of toothpaste. Today with the rapid growth of service industry marketers of different service organizations are facing huge challenges to meet up customers expectations. Therefore it is important for the service organizations to develop their brand in such a way so that customers are satisfied. The study has been conducted despite some of the limitations. The study is expected to contribute to the economic and social viewpoint in the country.

\subsection{Managerial Implications}

Brands are an essential part of consumer choices when purchasing products. Today customers see brand as an important part of the product. To build strong brand image marketers should find out the factors that affect the consumer's purchase decision on that specific brand. We know service industry is a very big industry. There is intense competition. With the help of this study marketers who are involved in toothpaste brands can easily identify the factors that affect the toothpaste brand selection decision of consumers. The study has found some of the key factors that affect the brand selection decision of toothpaste like quality, advantages of using product, duration of freshness, Smell, perceived performance, brand awareness, product attribute. Therefore while building a toothpaste brand marketer should focus on these factors so that they can attract consumers towards their brand. The study has identified some of the problems regarding developing a toothpaste brand like consumers prefer some attributes e.g. quality, advantages of using product, duration of freshness, Smell, perceived performance, brand awareness, product attribute in the brand. Since some factors e.g. Parents influence, Country of Origin, Price, Peer group influence, Design or packaging don't affect at all for the customers to select brand, marketers can give less emphasis on it.

\section{Appendix}

\section{Distribution of Sample}

Table 21: Number of respondents by age groups in the sample.

\begin{tabular}{cccccc}
\hline & \multicolumn{3}{c}{ Age } & & \\
& & $\begin{array}{c}\text { Freque } \\
\text { ncy }\end{array}$ & Percent & $\begin{array}{c}\text { Valid } \\
\text { Percent }\end{array}$ & $\begin{array}{c}\text { Cumulativ } \\
\text { e Percent }\end{array}$ \\
\hline \multirow{4}{*}{ Valid } & $15-25$ & 43 & 43.0 & 43.0 & 43.0 \\
& $26-35$ & 33 & 33.0 & 33.0 & 76.0 \\
& $36-45$ & 11 & 11.0 & 11.0 & 87.0 \\
& 46 -above & 13 & 13.0 & 13.0 & 100.0 \\
& Total & 100 & 100.0 & 100.0 & \\
\hline
\end{tabular}

Table 22: Number of respondents by gender groups in the sample.

\begin{tabular}{cccccc}
\hline & \multicolumn{4}{c}{ Gender } & \\
& & $\begin{array}{c}\text { Frequenc } \\
\text { y }\end{array}$ & Percent & $\begin{array}{c}\text { Valid } \\
\text { Percent }\end{array}$ & $\begin{array}{c}\text { Cumulative } \\
\text { Percent }\end{array}$ \\
\hline \multirow{4}{*}{ Valid } & Male & 53 & 53.0 & 53.0 & 53.0 \\
& $\begin{array}{c}\text { Female } \\
\text { Total }\end{array}$ & 47 & 47.0 & 47.0 & 100.0 \\
\hline
\end{tabular}

Table 23: Number of respondents by income groups in the sample.

\begin{tabular}{|c|c|c|c|c|c|}
\hline \multicolumn{6}{|c|}{ Income } \\
\hline & & $\begin{array}{c}\text { Frequen } \\
\text { cy }\end{array}$ & $\begin{array}{c}\text { Percen } \\
\mathrm{t}\end{array}$ & $\begin{array}{c}\text { Valid } \\
\text { Percent }\end{array}$ & $\begin{array}{c}\text { Cumulativ } \\
\text { e Percent }\end{array}$ \\
\hline \multirow{5}{*}{$\begin{array}{c}\text { Vali } \\
\text { d }\end{array}$} & $\begin{array}{c}\text { Less Than } \\
10000\end{array}$ & 61 & 61.0 & 61.0 & 61.0 \\
\hline & $10001-30000$ & 28 & 28.0 & 28.0 & 89.0 \\
\hline & $30001-40000$ & 8 & 8.0 & 8.0 & 97.0 \\
\hline & 40001-above & 3 & 3.0 & 3.0 & 100.0 \\
\hline & Total & 100 & 100.0 & 100.0 & \\
\hline
\end{tabular}

Table 24: Number of respondents by profession groups in the sample.

\begin{tabular}{|c|c|c|c|c|c|}
\hline \multicolumn{6}{|c|}{ Profession } \\
\hline & & $\begin{array}{c}\text { Frequen } \\
\text { cy }\end{array}$ & Percent & $\begin{array}{c}\text { Valid } \\
\text { Percent }\end{array}$ & $\begin{array}{c}\text { Cumulativ } \\
\text { e Percent }\end{array}$ \\
\hline \multirow{6}{*}{$\begin{array}{c}\text { Vali } \\
\text { d }\end{array}$} & $\begin{array}{c}\text { Govt. } \\
\text { Employee }\end{array}$ & 5 & 5.0 & 5.0 & 5.0 \\
\hline & $\begin{array}{c}\text { Businessma } \\
\mathrm{n}\end{array}$ & 11 & 11.0 & 11.0 & 16.0 \\
\hline & $\begin{array}{l}\text { Service } \\
\text { Holder }\end{array}$ & 27 & 27.0 & 27.0 & 43.0 \\
\hline & student & 42 & 42.0 & 42.0 & 85.0 \\
\hline & other & 15 & 15.0 & 15.0 & 100.0 \\
\hline & Total & 100 & 100.0 & 100.0 & \\
\hline
\end{tabular}




\section{References}

[1] Berkman, H. W. (1992). Twenty years of the journal. Journal of the Academy of Marketing Science, 20(4), 299-300.

[2] Bhasin. H, (2006). "Personal factors affecting consumer buying behavior". From www.marketing91.com

[3] Brian P. Brown, Alex R. Zablah, Danny N. Bellenger and Naveen Donthu (2012), "What Factors Influence Buying Center Brand Sensitivity?," Industrial Marketing Management 41(3), 508-520.

[4] Burmann C, Jost-Benz M, Riley N (2008). "Towards an identity-based brand equity model". J. Bus. Res., 62: 390397.

[5] Erenkol, A, D. and Duygun, A. (2010) Customers " perceived brand equity and a research on the customers of Bellona which is a Turkish furniture brand, The Journal of American Academy of Business, Vol.16, No. 1.

[6] Ghoderwar, Bhimrao (2008), "Building Brand Identity in Competitive Markets: A Conceptual Model", Journal of Product and Brand Management, Vol.17, No:1, pp.4-12.

[7] Gladden, J. M., \& Milne, G. R. 2004. Examining the Importance of Brand Equity in Professional Sport. In S. Rosner \& K. Shropshire (Eds.), The Business of Sports (pp. 188- 193). Massachusetts: Jones and Bartless Publishers.

[8] Jacoby, J., Olson, J. C., \& Haddock, R. A. (1971).Price, brand name and product composition characteristics as determinants of perceived quality. Journal of Applied Psychology, 55, 570-579.

[9] Jacoby, J., Speller, D., \& Berning, C. (1974). Brand choice behavior as a function of information load: Replication and extension. Journal of Consumer Research, 1 (1), 33-42.

[10] Kotler, P. and Keller, K.L. 2009.p276-p278, Marketing Management. 13th Edition, Pearson Prentice Hall, New Jersey.

[11] Kotler, P., \& Armstrong, G. (1996). Principles of Marketing (7 ed.). Upper Seddle River: Prentice-Hall.

[12] Low, G. S. and Lamb Jr, C. W. 2000. The Measurement and Dimensionality of Brand Associations, Journal of Product \& Brand Management, Vol. 9, No. 6, pp. 350-368.

[13] Mahalingam1, S., Kumar, P. Nandha, 2012, "A study on consumer behaviour towards selected fast moving consumer goods in Coimbatore city", Indian Journal of Education and Information Management, Vol: 5, Issue:11, pp 493-494
[14] Mahmud. k, G. Khonika, 2012, "Factors Influencing The Extent of Brand Loyalty of Toilet Soap Users in Bangladesh: A Case Study on Dhaka City", Global Journal of Management and Business Research, Volume 12 Issue 15, pp 1-2

[15] MOTAMENI, R. AND M. SHAHORKHI (1998), "Brand Equity Valuation: A Global Perspective", Journal of Product and Brand Management, 7 (4), 275-290.

[16] Mullarkey GW (2001). The influence of brands in the fashion purchasing process. University of Auckland Business Review, 3(1), 56-71.

[17] Puth, G., Mostert, P. and Ewing, M. (1999) Consumer Perceptions of Mentioned Product and Brand Attributes in Magazine Advertising, Journal of Product \& Brand Management, 8(1), pp. 38-49.

[18] Rajagopal (2008), Measuring Brand Performance through Metrics Application, Measuring Business Excellence, 12 (1), 29-38.

[19] Rao, Akshay R. and Kent B. Monroe. (1989). 'The Effect of Price, Brand Name, and Store Name on Buyers' Perceptions of Product Quality: An Integrative Review," Journal of Marketing Research, 26 (August): 351-357

[20] RICHARDSON. P. S. , A.S. DICK, and A.K. JAIN. 1994. Extrinsic and intrinsic cue effects on perceptions of store brand quality. Journal of Marketing 58: 28-36.

[21] Ronnie Ballantyne, Anne Warren, Karinna Nobbs (2006), "The evolution of brand choice", Journal of Brand Management, 13:339-352

[22] Shimp, T.A. and Bearden, W.O. (1982) 'Warranty and Other Extrinsic Cue Effects on Consumer's Risk Perceptions', Journal of Consumer Research 9: 38-46.

[23] Srivastava, R., Shervani, T., \& Fahey, L. (1998). Marketbased assets and shareholder value: A framework for analysis. Journal of Marketing, 62 (1), 2-18.

[24] Wel, C.B.A. Iche, Alam, S. Yed, Nor M. Sallehuddin, (2011) "Factors Affecting Brand Loyalty: An Empirical Study in Malaysia", Australian Journal of Basic and Applied Sciences, 5(12): 777-783, ISSN 1991-8178, PP. 777

[25] Yoo, B., Donthu, N,.Lee.B., (2000), "An Examination of elected Marketing Mix Elements and Brand Equity”. Journal of the Academy of Marketing Science.

[26] Zeithaml, V.A. (1988) Consumer perceptions of price, quality, and value: a means-end model and synthesis of evidence. Journal of Marketing 52(3): 2-22. https://en.wikipedia.org/wiki/Khulna 